УДК $631.11: 631.5: 631.81(477.7)$

Гамаюнова В. В., доктор сільськогосподарських наук,

Панфілова А. В., кандидат сільськогосподарських наук,

Миколаївський національний аграрний університет

\title{
ОКУПНІСТЬ СУМІСНОГО ВИКОРИСТАННЯ ДОБРИВ ТА БІОПРЕПАРАТІВ НА ПШЕНИЦІ ОЗИМОЇ В ПІВДЕННОМУ СТЕПУ УКРАЇНИ
}

\section{Рещензент - доктор сільськогосподарських наук М. І. Федорчук}

Метою роботи було удосконалення елементів технології вирощування сортів пшениці озимої в умовах Південного Степу України на засадах ресурсозберігаючого живлення рослин шляхом оброблення посіву рослин рістрегулюючими речовинами в основні періоди вегетації по фону основного внесення невисоких доз мінеральних добрив.

Методика дослідження. Експериментальні дослідження проводили впродовж 2011-2016 рр. на дослідному полі Миколаївського начіонального аграрного університету. Об'єктом досліджень була пшениия озима - сорти Кольчуга та Заможність. У дослідженнях застосовували загальноприйняті для зони методики досліджень. Урожайність визначали методом суиільного скошування з кожної облікової ділянки.

Результати дослідження. У результаті виконаної роботи встановлено, щэо у роки досліджень урожайність пшенииі озимої сорту Кольчуга коливалася в межах 2,89-4,48 m/2а, а сорту Заможність - 3,05-4,99 m/2а залежно від варіанту живлення. Найбільш оптимальним фон живлення складався за поєднання внесення помірної дози мінерального добрива і підживлення в період вегетації препаратами Органік Д2 та Ескорт - біо. Окупність приростом урожайності зерна в зазначених варіантах живлення пшеничі озимої сорту Кольчуга склала 25,50-26,50 кг, а сорту Заможність 31,83-32,33 к2.

Елементи наукової новизни. Набули подальшого розвитку питання ресурсозберігаючого живлення рослин пшениці озимої, у зв'язку з появою нових сортів, препаратів й зміною кліматичних $i$ трунтових умов.

Практична значущість одержаних результатів полягає в розробиі, удосконаленні й впровадженні у виробництво елементів технології вирощування пшениці озимої на чорноземі південному, яка забезпечує приріст урожайності зерна на рівні 1,59-1,94 m/2а залежно від сорту.

Ключові слова: пшениця озима, сорти, фон живлення, приріст урожайності зерна, окупність варіанту живлення.

Гамаюнова Валентина Василівна - доктор сільськогосподарських наук, професор, завідувач кафедри землеробства, геодезії та землеустрою, Миколаївський національний аграрний університет, вул. Г. Гонгадзе, 9, м. Миколаїв, 54020, Україна, e-mail: gamajunovaal@gmail.com, ORCID ID: 00000001-9471-8272.

Панфілова Антоніна Вікторівна - кандидат сільськогосподарських наук, доцент, доцент кафедри рослинництва та садово-паркового господарства, Миколаївський національний аграрний університет, вул. Г. Гонгадзе, 9, м. Миколаїв, 54020, Україна, e-mail: panfilovaantonina@ukr.net, ORCID ID: 0000-0003-0006-4090.

Постановка проблеми. Удосконалення технології вирощування пшениці озимої є надзвичайно актуальним завданням, оскільки в нинішніх економічних умовах здешевлення виробництва зерна та підвищення рентабельності його вирощування можливе лише в разі впровадження нових агротехнічних прийомів, які не передбачають великих затрат. Відомо, що найбільш вартісними 3 елементів технологій вирощування сільськогосподарських культур є заходи обробітку грунту та застосування добрив, останні ж і

особливо у сучасних умовах господарювання, коли грунти $є$ збідненими на елементи живлення $\epsilon$ найбільш дієвим фактором підвищення врожаїв $[11,12]$. У зв'язку з цим оптимізація живлення рослин на засадах ресурсозбереження, а саме використання в період вегетації сучасних рістрегулюючих препаратів, має істотні перспективи для широкого впровадження.

Аналіз останніх досліджень та публікацій, у яких започатковано розв'язання проблеми. В аграрному секторі країни відбулися суттєві 


\section{СІЛЬСЬКЕ ГОСПОДАРСТВО. РОСЛИННИЦТВО}

зміни пріоритетів щодо вирощування економічно вигідних культур. У більшості господарств пшениця озима щороку займає значну частину посівних площ, що суттєво впливає як на економічні показники господарства, так i аграрного комплексу загалом. Одним із основних показників при цьому є врожайність, яка є результатом комплексної взаємодії між генетичними особливостями рослин, характеристикою грунтових властивостей, агротехнікою та кліматичними умовами [15]. Пшениця озима є основною зерновою культурою, яка займає біля 40 \% посівних площ зернових культур в Україні і забезпечує понад $50 \%$ валових зборів зерна. Потенційні можливості сучасних сортів цієї культури сягають 8-15 т/га, проте у виробництві середня врожайність зерна в Україні становить 2,8-3,5 т/га або не перевищує 30-50 \% від можливого рівня $[3,6,5]$. Завдання аграріїв полягає в істотному збільшенні врожайності й поліпшенні якості зерна пшениці озимої, що дозволить стабілізувати зерновиробництво цієї культури [1]. На врожайність і якість зерна чи не найбільшою мірою впливає оптимізація живлення.

Одним із резервів підвищення врожайності сільськогосподарських культур, зокрема пшениці озимої, та їі стабільності за роками є своєчасне впровадження у виробництво нових високоврожайних сортів високої якості [5]. Створення сортів пшениці озимої з підвищеною стійкістю до несприятливих чинників, які визначають умови існування рослин та їх фізіологічний стан, забезпечує стабільне отримання високих урожаїв незалежно від мінливості погодних умов, що $є$ дуже важливим в останні роки [14].

Запорукою отримання високої врожайності i якості продукції, зокрема й пшениці озимої, $є$ впровадження ефективних технологій вирощування. До важливих елементів агротехніки слід віднести раціональне застосування добрив, регуляторів росту, біопрепаратів [9, 10, 12]. Проблематику оптимізації систем удобрення зернових культур досить докладно представлено в останніх публікаціях українських та закордонних вчених $[4,11,13,16]$, проте низка питань залишається ще недостатньо дослідженими, зокрема оптимізація живлення, яку необхідно вивчати і у зв'язку 3 появою нових сортів та гібридів рослин.

Показники ефективності використання добрив є одними з основних та характеризують діяльність сільськогосподарських підприємств. Від внесеної їх кількості залежить об'єм вирощеної продукції, вартість іiі реалізації, рівень собівартості, прибутку, рентабельності, фінансовий стан підприємства, його платоспроможність та інші важливі економічні показники. Тому аналізуючи господарську діяльність, доцільно визначити ефективність використання добрив [2].

Метою наших досліджень було удосконалення елементів технології вирощування сортів пшениці озимої в умовах Південного Степу України на засадах ресурсозберігаючого живлення рослин шляхом оброблення посіву рослин рістрегулюючими речовинами в основні періоди вегетації по фону основного внесення невисоких доз мінеральних добрив.

Завдання досліджень - визначити вплив сортових особливостей та ресурсозберігаючого живлення рослин на врожайність пшениці озимої та визначити окупність сумісного використання мінеральних добрив та рістрегулюючих речовин.

Матеріали і методи досліджень. Експериментальні дослідження проводили впродовж 2011-2016 pр. на дослідному полі Миколаївського НАУ. Об'єктом досліджень були сорти пшениці озимої Кольчуга та Заможність. Технологія їхнього вирощування, за винятком досліджуваних факторів, була загальноприйнятою до існуючих зональних рекомендацій для Південного Степу України. Погодні умови в роки досліджень різнилися, зокрема, упродовж вегетації у 2015-2016 рр. випало значно більше опадів. За температурним режимом вони були типовими для південної зони Степу України.

Грунт дослідних ділянок представлений чорноземом південним, залишковослабкосолонцюватим важкосуглинковим на лесах. Реакція грунтового розчину нейтральна $(\mathrm{pH}-6,8-7,2)$. Вміст гумусу в шарі 0-30 см становить 3,3\%. Рухомих форм елементів живлення в орному шарі грунту в середньому містилося: нітратів (за ГрандвальЛяжу) - 18, рухомого фосфору (за Мачигіним) 49, обмінного калію (на полуменевому фотометpi) -395 мг/кг грунту.

Схема досліду включала наступні варіанти:

Фактор А - сорт: 1. Кольчуга; 2. Заможність.

Фактор В - живлення: 1. Контроль (без добрив та рістрегулюючих речовин); 2. $\mathrm{N}_{30} \mathrm{P}_{30}-$ під передпосівну культивацію - фон; 3. Фон +Мочевин К1 (1 л/га); 4. Фон + Мочевин К2 (1 л/га); 5. Фон + Ескорт-біо (0,5 л/га); 6. Фон + Мочевин К1 + Мочевин К2 (по 0,5 л/га); 7. Фон + Органік Д2 (1 л/га). Норма робочого розчину складала 200 л/га. Підживлення посівів сучасними рістрегулюючими речовинами проводили двічі на початку відновлення весняної вегетації та на початку виходу рослин пшениці озимої у трубку.

Препарати, що взяті на вивчення для прове- 
дення позакореневих підживлень посівів пшениці озимої, внесені до Переліку пестицидів і агрохімікатів, дозволених до використання в Україні. Препарати Мочевин К1 та Мочевин К2 зареєстровані як добрива, що містять відповідно $\mathrm{N}-11-$ $13 \%, \mathrm{P}_{2} \mathrm{O}_{5}-0,1-0,3 \%, \mathrm{~K}_{2} \mathrm{O}-0,05-0,15 \%$, мікроелементи - 0,1\%, бурштинову кислоту - 0,1\% та $\mathrm{N}-9-11 \%, \mathrm{P}_{2} \mathrm{O}_{5}-0,5-0,7 \%, \mathrm{~K}_{2} \mathrm{O}-0,05-$ $0,15 \%$, гумат натрію - 3 г/л, гумат калію - 1 г/л, мікроелементи - 1 г/л. Органік Д2 - органомінеральне добриво, яке містить $\mathrm{N}-2,0-3,0 \%$, $\mathrm{P}_{2} \mathrm{O}_{5}-1,7-2,8 \%, \mathrm{~K}_{2} \mathrm{O}-1,3-2,0 \%$, кальцію загального - 2,0-6,0\%, органічних речовин - 6570 \% (у перерахунку на вуглець). Ескорт біоприродний мікробний комплекс, який містить штами мікроорганізмів родів Azotobacter, Pseudomonas, Rhizobium, Lactobacillus, Bacillus i продуковані ними біологічно активні речовини (БАР).

У дослідженнях застосовували загальноприйняті для зони методики досліджень [8]. Урожайність визначали методом суцільного скошування 3 кожної облікової ділянки (комбайн «Сампо-130»).

Результати досліджень. Проведені нами дослідження свідчать, що в роки вирощування, урожайність зерна пшениці озимої сорту Кольчуга коливалася у межах 2,89-4,48 т/га, а сорту Заможність - 3,05-4,99 т/га залежно від варіанту живлення (див. рис.).

У середньому за роки досліджень по фактору оптимізації живлення дещо вищу врожайність формував сорт Заможність - 4,43 т/га, що більше порівняно з сортом Кольчуга на 0,41 т/га або на $9,3 \%$.

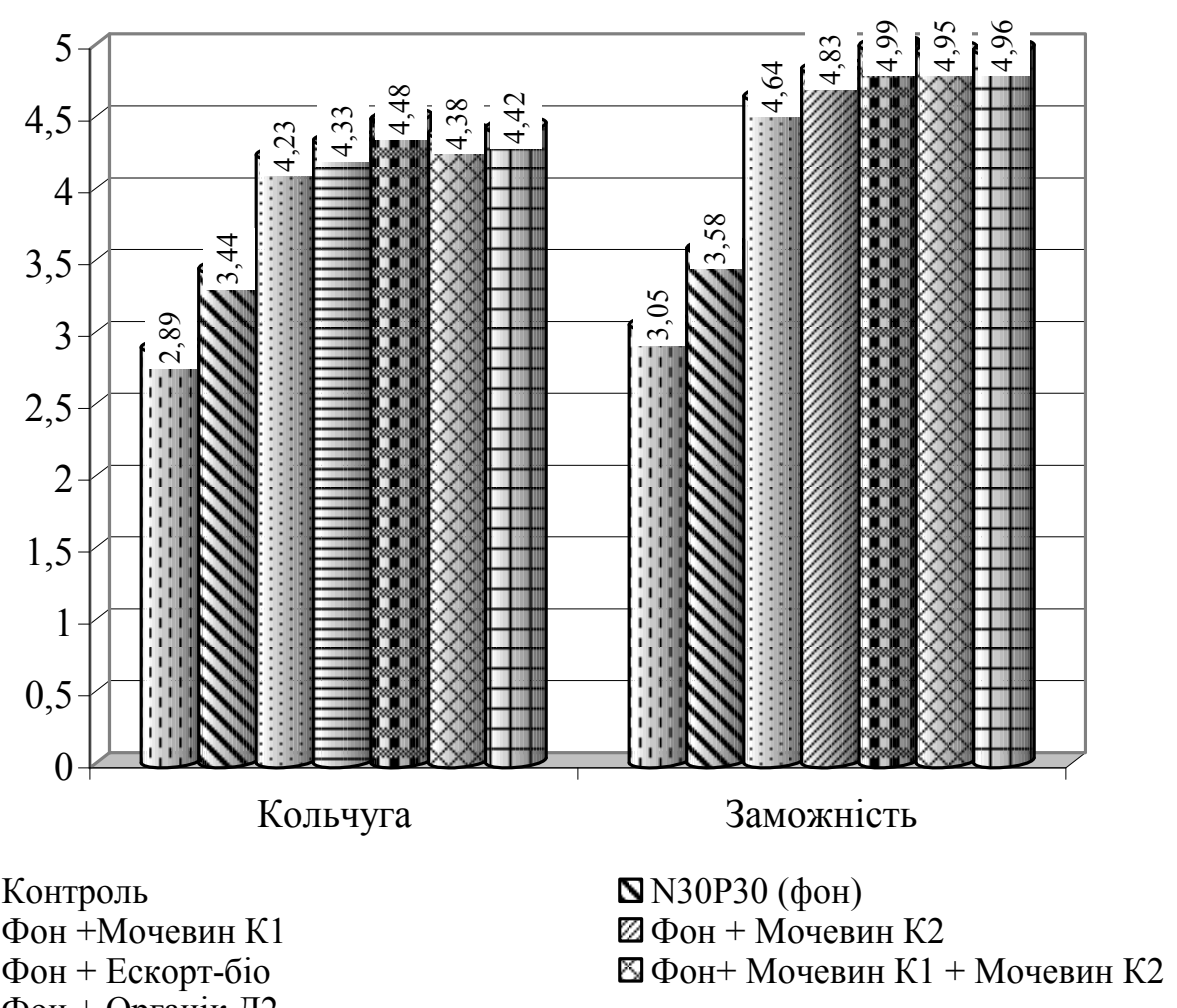

Рис. Урожайність пшениці озимої залежно від сортових особливостей та оптимізації жсивлення (середнс за 2012-2016 рp.), m/2а

Джерело: власні дослідження. 
СІЛЬСЬКЕ ГОСПОДАРСТВО. РОСЛИННИЦТВО

Окупність мінеральних добрив та рістрегулюючих речовин приростом урожаю зерна сортів пшениці озимої (середне за 2012-2016 рр.)

\begin{tabular}{|c|c|c|c|}
\hline \multirow[b]{2}{*}{ Варіант живлення } & \multicolumn{3}{|c|}{ Показники } \\
\hline & $\begin{array}{c}\text { Приріст урожайності } \\
\text { зерна до контролю, } \\
\text { т/га }\end{array}$ & $\begin{array}{c}\text { Загальний показник } \\
\text { окупності від опти- } \\
\text { мізації живлення }\end{array}$ & $\begin{array}{c}\text { У т.ч. від підживлен- } \\
\text { ня препаратами }\end{array}$ \\
\hline \multicolumn{4}{|c|}{ Сорт Кольчуга } \\
\hline Контроль & 0,0 & 0,00 & 0,00 \\
\hline $\mathrm{N}_{30} \mathrm{P}_{30}(\phi о н)$ & 0,55 & 9,17 & 0,00 \\
\hline Фон +Мочевин К1 & 1,34 & 22,33 & 13,16 \\
\hline Фон + Мочевин К2 & 1,44 & 24,00 & 14,83 \\
\hline Фон + Ескорт-біо & 1,59 & 26,50 & 17,33 \\
\hline $\begin{array}{l}\text { Фон+ Мочевин К1 + } \\
\text { Мочевин К2 }\end{array}$ & 1,49 & 24,80 & 15,66 \\
\hline Фон + Органік Д2 & 1,53 & 25,50 & 16,33 \\
\hline \multicolumn{4}{|c|}{ Сорт Заможність } \\
\hline Контроль & 0,0 & 0,00 & 0,00 \\
\hline $\mathrm{N}_{30} \mathrm{P}_{30}($ фон $)$ & 0,53 & 8,83 & 0,00 \\
\hline Фон +Мочевин К1 & 1,59 & 26,50 & 17,67 \\
\hline Фон + Мочевин К2 & 1,78 & 29,67 & 20,84 \\
\hline Фон + Ескорт-біо & 1,94 & 32,33 & 23,50 \\
\hline $\begin{array}{l}\text { Фон+ Мочевин К1 + } \\
\text { Мочевин К2 }\end{array}$ & 1,90 & 31,67 & 22,84 \\
\hline Фон + Органік Д2 & 1,91 & 31,83 & 23,00 \\
\hline
\end{tabular}

Джерело: власні дослідження.

Визначено, що приріст урожаю зерна пшениці озимої обох досліджуваних нами сортів найбільшим був за проведення двох підживлень посівів рослин у період вегетації препаратами Органік Д2 та Ескорт-біо по фону внесення мінеральних добрив у дозі $\mathrm{N}_{30} \mathrm{P}_{30}$ (див. табл.).

За такого поєднання добрив i препаратів приріст урожаю зерна пшениці озимої сорту Кольчуга склав 1,53-1,59 т/га або 34,6-35,5\%, а сорту Заможність - 1,91-1,94 т/га або 38,5$38,9 \%$ порівняно до контролю. Дещо меншим приріст урожаю визначено у варіанті сумісного застосування Мочевин К1 та Мочевин К2 - у межах 1,49-1,92 т/га або 34,0-38,6 \% залежно від сорту.

При включенні будь-яких елементів у технологію вирощування сільськогосподарських культур, зокрема добрив, доцільно визначити їхній вплив на рівень урожаю, його приріст на окупність приростом урожаю.

Практикою підтверджено, що найвищою окупність одиниці добрив приростом урожаю визначена при застосуванні невисоких їх доз. Проте оскільки приріст урожаю з одиниці площі від невисоких доз добрив також незначний, то витрати на їх внесення не завжди можуть окупа- тися приростом урожаю. За збільшення доз добрив до певного рівня приріст урожаю і прибутку, як правило, зростають, проте окупність одиниці добрива додатково сформованим урожаєм може поступово знижуватися. 3 подальшим підвищенням доз добрив до певного рівня приріст урожаю вже не окуповується витратами на їх внесення [7]. Окупність внесеної помірної дози мінеральних добрив у наших дослідах залежала від узятого на дослідження сорту пшениці озимої. У середньому за роки досліджень окупність одного кілограма діючої речовини мінеральних добрив приростом урожайності зерна пшениці озимої сорту Кольчуга склала 9,17 кг, що перевищило цей показник у сорту Заможність на 0,34 кг або на $3,9 \%$.

Проведення позакореневих підживлень рослин у період вегетації сучасними рістрегулюючими препаратами по фону $\mathrm{N}_{30} \mathrm{P}_{30}$ забезпечувало окупність їх використання приростом урожайності зерна пшениці озимої сорту Кольчуга на рівні 13,16-17,33, сорту Заможність - 17,67-23,50 кг.

Найбільш ефективним варіантом оптимізації живлення, у середньому за роки досліджень, було внесення помірної дози мінерального добрива до сівби, а саме $\mathrm{N}_{30} \mathrm{P}_{30}$ і проведення двох позако- 
реневих підживлень у період вегетації препаратами Органік Д2 та Ескорт - біо. Окупність у зазначених варіантах живлення приростом урожайності зерна пшениці озимої сорту Кольчуга склала 25,50 - 26,50 кг, а сорту Заможність 31,83-32,33 кг.

Визначено, що рослини пшениці озимої сорту Заможність щонайбільше реагували на поєднання мінеральних добрив та рістрегулюючих речовин.

Висновок. В умовах Південного Степу України при вирощуванні пшениці озимої дещо більшою окупність сумісного застосування кіло-

\section{БІБЛІОГРАФІЯ}

1. Гамаюнова В. В., Литовченко А. О. Реакція сортів пшениці озимої на фактори та умови вирощування в зоні Степу України. Вісник Харківського національного аграрного університету. 2017. № 1. C. 43-52.

2. Ионас B. A. Система удобрения сельскохозяйственных культур. Минск : Ураджай, 1998. 287 c.

3. Зв'ягін А. Ф., Усова З. В., Іодковський В. З., Кібліцька О. С. Особливості селекції сортів озимої пшениці універсального типу з підвищеним адаптивним потенціалом у Східному Лісостепу України. Вісник Центру наукового забезпечення агропромислового виробництва Харківської області. Харків. 2012. Вип. 12. С. 89-93.

4. Каленська С., Холодченко Р., Токар Б. Вплив мінеральних добрив та ретардного захисту на урожайність ячменю ярого пивоварного. Агробіологія. 2015. Вип. 1(117). С. 56-58.

5. Коломієиь Л.А., Гуменюк О.В., Дергачов О. Л., Коляденко С. С. Новий сорт пшениці озимої «Горилиця миронівська». Plant Varieties Studying and Protection. 2018. Vol. 14. № 1. C. 2126. doi: 10.21498/2518-1017.14.1.2018.126499.

6. Корчинський А. А., Шевчук М. С., Андрющен$\kappa o$ A. B. Агроекологічні та адаптивні принципи формування і використання сортових ресурсів України. Plant Varieties Studying and Protection. 2010. № 1. C. 48-52. doi: 10.21498/2518-1017.1 (11).2010.59414

7. Лавренко С. О., Лавренко Н. М. Ефективність використання мінеральних добрив та поливної води посівами нуту залежно від технологічних прийомів його вирощування в умовах Південного Степу України. Молодий вчений. 2015. № 2(17). C. $72-75$.

8. Методика державного сортовипробування сільськогосподарських культур. Вип. 2. Зернові, круп'яні та зернобобові культури ; під ред. грама діючої речовини мінеральних добрив та позакореневих підживлень сучасними препаратами приростом урожаю зерна визначена за вирощування сорту Заможність. Проведення двох позакореневих підживлень посівів на початку відновлення весняної вегетації та початку виходу рослин у трубку препаратами Ескорт - біо та Органік Д2 по фону $\mathrm{N}_{30} \mathrm{P}_{30}$ забезпечує формування найбільших приростів урожайності зерна досліджуваних сортів пшениці озимої - 1,531,59 та 1,91-1,94 т/га порівняно до контролю та зростанню окупності варіантів оптимізації живлення до 25,50-26,50 та 31,83-32,33 кг зерна.

В. В. Волкодава. Київ, 2001. 65 с.

9. Ноздріна Н. Л. Формування елементів структури врожайності та якості зерна нових сортів пшениці озимої в Північному Степу. Вісник Полтавської державної аграрної академії. 2014. № 2. C. 165-168.

10. Носко Б. С. Сучасний стан та перспективні напрямки досліджень в агрохімії. Вісник аграрної науки. 2002. № 9. С. 9-12.

11. Панфілова А. В., Гамаюнова В. В. Продуктивність сортів ячменю ярого залежно від оптимізації живлення в умовах Південного Степу України. Plant Varieties Studying and Protection. 2018. Vol. 14. № 3. C. 310-315. doi: 10.21498/25181017.14.3.2018.145304.

12. Ситник В. П. Екологічні аспекти агропромислового комплексу. Вісник аграрної науки. 2002. № 9. С. 55-57.

13. Buráňová Š., Černý J., Mitura K., Lipińska K. J., Kovářik J., Balik J. Effect of organic and mineral fertilizers on yield parameters and quality of wheat grain. Scientia agriculturae bohemica. 2016 (2). Vol. 47. P. 47-53. doi: 10.1515/sab-2016-0008.

14. Blum A. Plant breeding for stress en vironments. Boca Raton, Florida : CRC Press, 1988. $223 \mathrm{p}$.

15. Diacono M., Castrignano A., Troccoli A., DeBenedetto D., Basso B., \& Rubino P. Spatial and temporal variability of wheat grain yield and quality in a Mediterranean environment: A multivariate geostatistical approach. Field Crops Research. 2012. Vol. 131. P. 49-62. doi: 10.1016/j.fcr.2012.03.004.

16. Piskaeva A. I., Babich O. O., Dolganyuk V.F. Analysis of influence of biohumus on the basis of consortium of effective microorganism son the productivity of winter wheat. Foods and raw material. 2017. Vol. 5(1). P. 90-99. doi: 10.21179/2308-4057-2017-190-99. 


\section{REFERENCES}

1. Hamaiunova, V. V., Lytovchenko, A. O. (2017). Reaktsiia sortiv pshenytsi ozymoi na faktory ta umovy vyroshchuvannia $\mathrm{v}$ zoni Stepu Ukrainy [Reaction of winter wheat grades on the factors and conditions of cultivation in a zone of the Steppe in Ukraine]. Visnyk Kharkivskoho natsionalnoho ahrarnoho universytetu, 1, pp. 43-52 [In Ukrainian].

2. Yonas, V. A. (1998). Systema udobrenyia selskokhoziaistvennykh kultur [System of Fertilization of Agricultural Cultures]. Mynsk: Uradzhai. [In Russian].

3. Zviahin, A. F., Usova, Z. V., Iodkovskyi, V. Z., Kiblitska, O. S. (2012). Osoblyvosti selektsii sortiv ozymoi pshenytsi universalnoho typu $\mathrm{Z}$ pidvyshchenym adaptyvnym potentsialom $u$ Skhidnomu Lisostepu Ukrainy [Peculiarities of selection of winter wheat varieties of the universal type with the increased adaptive potential in the Eastern Forest-steppe of Ukraine]. Visnyk Tsentru naukovoho zabezpechennia ahropromyslovoho vyrobnytstva Kharkivskoi oblasti, 12, pp. 89-93 [In Ukrainian].

4. Kalenska, S., Kholodchenko, R., Tokar, B. (2015). Vplyv mineralnykh dobryv ta retardnoho zakhystu na urozhainist yachmeniu yaroho pyvovarnoho [Effect of mineral fertilizers and retard protection on yield of barley of spring brewing]. Ahrobiolohiia, 1 (117), pp. 56-58 [In Ukrainian].

5. Kolomiiets, L. A., Humeniuk, O. V., Derhachov, O. L., Koliadenko, S. S. (2018). Novyi sort pshenytsi ozymoi 'Horylytsia myronivska [A new variety of soft winter wheat 'Horlytsia myronivska']. Plant Varieties Studying and Protection, 14 (1), pp. 21-26. doi: 10.21498/25181017.14.1.2018.126499 [In Ukrainian].

6. Korchynskyi, A. A., Shevchuk, M. S., Andriushchenko, A. V. (2010). Ahroekolohichni ta adaptyvni pryntsypy formuvannia i vykorystannia sortovykh resursiv Ukrainy [Agroecological and adaptive principles of formation and use of varietal resources of Ukraine]. Plant Varieties Studying and Protection, 1, pp. 48-52. doi: 10.21498/25181017.1(11).2010.59414 [In Ukrainian].

7. Lavrenko, S. O., Lavrenko, N. M. (2015). Efektyvnist vykorystannia mineralnykh dobryv ta polyvnoi vody posivamy nutu zalezhno vid tekhnolohichnykh pryiomiv yoho vyroshchuvannia $\mathrm{v}$ umovakh Pivdennoho Stepu Ukrainy [Efficiency of applying fertilizers and irrigation water for chickpea crops depending on technological methods of its cultivation in the southern steppe of Ukraine]. Molodyi vchenyi, 2 (17), pp. 72-75 [In Ukrainian].

8. Volkodava V. V. (Ed.) (2001). Metodyka derzhavnoho

sortovyprobuvannia silskohospodarskykh kultur : Vyp. 2 (zernovi, krupiani ta zernobobovi kultury) [The method of state variety testing of agricultural crops]. (Vol. 2). Kyiv [In Ukrainian].

9. Nozdrina, N. L. (2014). Formuvannia elementiv struktury vrozhainosti ta yakosti zerna novykh sortiv pshenytsi ozymoi v Pivnichnomu Stepu [Formation of structure units of yielding capacity and quality of grain of new winter wheat varieties in northern Steppe]. Visnyk Poltavskoi derzhavnoi ahrarnoi akademii, 2, pp. 165-168 [In Ukrainian].

10. Nosko, B. S. (2002). Suchasnyi stan ta perspektyvni napriamky doslidzhen $\mathrm{v}$ ahrokhimii [Current state and perspective directions of research in agrochemistry]. Visnyk ahrarnoi nauky, 9, pp. 912 [In Ukrainian].

11. Panfilova, A. V., Hamaiunova, V. V. (2018). Produktyvnist sortiv yachmeniu yaroho zalezhno vid optymizatsii zhyvlennia $\mathrm{v}$ umovakh Pivdennoho Stepu Ukrainy [The productivity of spring barley varieties and plant nutrition optimization in the Southern Steppe of Ukraine]. Plant Varieties Studying and Protection, 14 (3), pp. 310-315. doi: 10.21498/25181017.14.3.2018.145304 [In Ukrainian].

12. Sytnyk, V. P. (2002). Ekolohichni aspekty ahropromyslovoho kompleksu [Environmental aspects of agro-industrial complex]. Visnyk ahrarnoi nauky, 9, pp. 55-57 [In Ukrainian].

13. Buráňová, Š., Černý, J., Mitura, K., Lipińska, K. J., Kováŕík, J., Balík, J. (2016). Effect of organic and mineral fertilizers on yield parameters and quality of wheat grain. Scientia agriculturae bohemica, 47 (2), pp. 47-53. doi: 10.1515/sab-2016-0008 [In English].

14. Blum, A. (1988). Plant breeding for stress en vironments. Boca Raton, Florida: CRC Press [In English].

15. Diacono, M., Castrignano, A., Troccoli, A., DeBenedetto, D., Basso, B., \& Rubino, P. (2012). Spatial and temporal variability of wheat grain yield and quality in a Mediterranean environment: A multivariate geostatistical approach. Field Crops Research, 131, pp. 49-62. doi: 10.1016/j.fcr.2012.03.004 [In English].

16. Piskaeva, A. I., Babich, O. O., Dolganyuk, V. F. (2017). Analysis of influence of biohumus on the basis of consortium of effective microorganism son the productivity of winter wheat. Foods and raw material, 5 (1), pp. 90-99. doi: 10.21179/2308-4057-2017-1-90-99 [In English]. 
Гамаюнова В. В., Панфилова А. В. Окупаемость совместного использования удобрений и внекорневых подкормок биопрепаратами на посевах пщеницы озимой в Южной Степи Украины

Целью работы было усовершенствование элементов технологии вырашивания сортов озимой пшенииы в условиях Южной Степи Украины на основе ресурсосберегающего питания растений путем обработки посева растений рострегулирующими веществами в основные периоды вегетации по фону основного внесения невысоких доз минеральных удобрений.

Методика исследования. Экспериментальные исследования проводили в течение 2011-2016 г2. на опытном поле Николаевского НАУ. Объектом исследований была пшеница озимая - сортов Кольчуга и Заможность. В исследованиях применяли общепринятые для зоны методики исследований. Урожайность определяли методом сплошного скашивания с каждого учетного участка.

Результаты исследования. Результаты исследований свидетельствуют, что в среднем за годы воздельвания урожайность пшенищь озимой сорта Кольчуга составила 2,89-4,48 m/2a, а Заможность - 3,05-4,99 m/2а в зависимости от варианта питания. Наиболее эффективным в оптимизации питания в среднем за годы исследований оказалось применение внесения подкормки в период вегетаиии препаратами Органик Д2 и Эскорт-био по фону умеренной дозы минерального удобрения. Так, окупаемость удобрений и препаратов в указанных вариантах питания приростом урожайности зерна пшеницы озимой сорта Кольчуга составила 25,50-26,50 к2, а сорта Заможсность - 31,8332,33 кг/кг удобрений совместно с рострегулирующими препаратами.

Элементы научной новизны. Получили дальнейтее развитие вопросы ресурсосберегающего питания растений озимой пшениць в связи с появлением новых сортов, препаратов и изменением климатических и почвенных условий.

Практическая значимость исследования заключается в разработке, совершенствовании и внедрении в производство элементов технологии выращивания озимой пшеницы на черноземе южном, которая обеспечивает прирост урожайности зерна на уровне 1,59-1,94 m/2a в зависимости от сор$m a$.

Ключевые слова: пшеница озимая, сорта, фон питания, прирост урожайности зерна, окупаемость совместного применения удобрений и рострегулирующих препаратов.

Гамаюнова Валентина Васильевна - доктор сельскохозяйственных наук, профессор, заведующая кафедрой земледелия, геодезии и землеустройства, Николаевский национальный аграрный университет, ул. Г. Гонгадзе, 9, г. Николаев, 54020, Украина, e-mail: gamajunovaal@gmail.com, ORCID ID: 0000-0001-9471-8272.

Панфилова Антонина Викторовна - кандидат сельскохозяйственных наук, доцент кафедры растениеводства и садово-паркового хозяйства, Николаевский национальный аграрный университет ул. Г. Гонгадзе, 9, г. Николаев, 54020, Украина, e-mail: panfilovaantonina@ukr.net, ORCID ID: 00000003-0006-4090.

Gamaiunova V. V., Panfilova A. V. Repayment of co-using fertilizers and foliar nutrition biopreparations on crops of winter wheat in the Southern Steppe of Ukraine

The purpose of the work was improving the elements of the cultivation technology of winter wheat varieties in the conditions of the Southern Steppe of Ukraine on the basis of resource-saving plant nutrition by treating the plants with the growth-regulating preparations during the main vegetation periods on the background of the main applying low doses of mineral fertilizers.

Methods of research. Experimental studies were conducted during 2011-2016 in the experimental field of Mykolaiv NAU. The objects of the research were such winter wheat varieties as Kolchuha and Zamozhnist. Generally accepted methods for the given research area were used in the experiments. The yield was determined by the method of overall mowing from each accounting area.

The research results. The studies have shown that, over the years of the research, the winter wheat yield of Kolchuha variety was 2.89-4.48 t/ha, and the yield of Zamozhnist variety was 3.05-4.99 t/ha, depending on the variant of nutrition. The most effective variant of crop nutrition, over the years of research, was the application of a moderate dose of mineral fertilizers and additional fertilization during the vegetation period with the preparations "Organic D2" and "Escort-bio". Thus, using these nutrition variants has resulted in yield increasing of Kolchuha winter wheat variety to $25.50-26.50 \mathrm{~kg}$, and of Zamozhnist variety - to 31.83$32.33 \mathrm{~kg}$. 
The elements of scientific novelty. The questions of the resource-saving nutrition of winter wheat plants, in connection with the appearance of new varieties, preparations and changes of climatic and soil conditions have been considered.

The practical significance of the obtained results is the development, improvement and introduction into production of the elements of winter wheat cultivation technology in the Southern black soil, as this crop provides grain yield growth at the level of 1.59-1.94 tons/ha depending on the variety.

Key words: winter wheat, varieties, nutrition background, grain yield growth, repayment of the nutrition variant.

Gamaiunova Valentyna Vasylivna - Doctor of Agricultural Sciences, Professor, Head of the Department of Arable Farming, Geodesy and Land Management, Mykolaiv National Agrarian University, 9, G. Gongadze st., Mykolaiv, 54020, Ukraine, e-mail: gamajunovaal@gmail.com, ORCID ID: 0000-00019471-8272.

Panfilova Antonina Viktorivna - Candidate $(\mathrm{PhD})$ of Agricultural Sciences, Associate Professor of the Department of Plant Growing, Gardens and Parks, Mykolaiv National Agrarian University, 9, G. Gongadze st., Mykolaiv, 54020, Ukraine, e-mail: panfilovaantonina@ukr.net, ORCID ID: 0000-0003-0006-4090.

Стаття надійшла до редакції 01.03.2019 р.

Бібліографічний опис для цитування :

Гамаюнова В. В., Панфілова А. В. Окупність сумісного використання добрив та біопрепаратів на пшениці озимої в Південному Степу України. Вісник ПДАА. 2019. № 1. С. 41-48.

DOI 10.31210/visnyk2019.01.05

(C) Гамаюнова Валентина Василівна, Панфілова Антоніна Вікторівна, 2019 